\title{
New or Rarely Reported Lichens for Thrace, Greece
}

Christensen, Steen N.

Published in:

Herzogia

DOI:

10.13158/heia.31.1.2018.390

Publication date:

2018

Document license:

CC BY-NC

Citation for published version (APA):

Christensen, S. N. (2018). New or Rarely Reported Lichens for Thrace, Greece. Herzogia, 31(p1), 390-394. https://doi.org/10.13158/heia.31.1.2018.390 


\section{BioOne COMPLETE}

\section{New or Rarely Reported Lichens for Thrace, Greece}

Source: Herzogia, 31(p1) : 390-394

Published By: Bryological and Lichenological Association for Central Europe

URL: https://doi.org/10.13158/heia.31.1.2018.390

BioOne Complete (complete.BioOne.org) is a full-text database of 200 subscribed and open-access titles in the biological, ecological, and environmental sciences published by nonprofit societies, associations, museums, institutions, and presses.

Your use of this PDF, the BioOne Complete website, and all posted and associated content indicates your acceptance of BioOne's Terms of Use, available at www.bioone.org/terms-of-use.

Usage of BioOne Complete content is strictly limited to personal, educational, and non-commercial use. Commercial inquiries or rights and permissions requests should be directed to the individual publisher as copyright holder. 


\title{
New or rarely reported lichens for Thrace, Greece
}

\author{
Steen N. CHRISTENSEN
}

\begin{abstract}
Christensen S.N. 2018: New or rarely reported lichens for Thrace, Greece. - Herzogia 31: 390-394.
Forty five species are reported from Thrace. Tree taxa, Cladonia caespiticia, Dermatocarpon luridum, and Vahliella leucophaea, are new to the Greek mainland, and 34 taxa are new to Thrace. This is at the same time a first record of lichens on Quercus frainetto in Greece.
\end{abstract}

Zusammenfassung: Christensen S.N. 2018: Neue und seltene Flechten von Thrakien, Griechenland. - Herzogia 31: $390-394$

Es werden fünfundvierzig Flechten aus Thrakien gemeldet. Drei Arten (Cladonia caespiticia, Dermatocarpon luridum und Vahliella leucophaea) sind neu für das griechische Festland, vierunddreißig Arten sind neu für Thrakien. Erstmals werden Flechten auf Quercus frainetto in Griechenland nachgewiesen.

Key words: Quercus frainetto, lichenized fungi, Rhodope Mountains

\section{Introduction}

The knowledge of the Greek lichenized mycota is gradually increasing (see references in CHRISTENSEN 2018). Lichenologists and other collectors have travelled in many parts of the

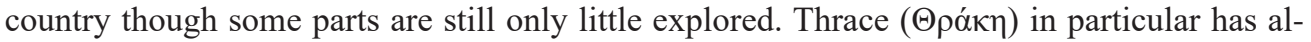
most been ignored by lichen collectors. With only 32 recorded species Thrace is the least known province of Greece (Аввотт 2009). ARCADIA (2018), however, state the number for Thrace to be 40. For the regional units ('nomi') Evros, Rodopi, and Xanthi only 19, 0 and 14 taxa are reported, respectively (Аввотт 2009, ARCADIA 2018). This paper is a small contribution to increase the knowledge of the lichens inhabiting this north-easternmost part of mainland Greece. A first record of the lichens on Quercus frainetto is given.

\section{Materials and methods}

Specimens were determined using standard procedures (SмIтн et al. 2009), except that thinlayer chromatography and other chromatographic techniques were not available.

The specimes are deposited in Natural History Museum of Denmark, Botanical Garden \& Museum, Copenhagen (C), in Botanical Garden \& Museum, Berlin-Dahlem (B) and in the authors private herbarium. No papers dealing with the lichen mycota of Thrace have appeared since the Greek checklist (Аввотт 2009) was published, so the presence and absence of the collected species were only checked against this work. Taxa not included in Аввотт (2009) were checked against subsequent papers (see Christensen 2018). 
Unfortunately two consecutively collected specimens (Cladonia fimbriata and C. glauca) were given the same number (15871). To indicate that it is not a divided specimen $C$. fimbriata is given the number $15871 \mathrm{x}$.

To facilitate comparisons with previous publications a conservative view of nomenclature and taxonomy in Collemataceae is taken (new names are given in parentheses).

\section{The localities}

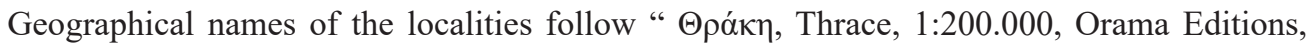
Travel Bookstore, Athens”.

1) Nomos Xanthis: about $26 \mathrm{~km}$ NNE of Xanthi town, E of the village Kidaris, Rodopi Mts, E of Mt Therma (897 m). $41^{\circ} 21.066^{\prime} \mathrm{N} 25^{\circ} 01.649^{\prime} \mathrm{E}$. Open sheep and goat grazed Quercus frainetto woodland with Acer monspessulanum and Carpinus on small ridge with limestone outcrops. On trunk of Quercus frainetto. Alt. 698 m. 14.09.2017.

2) Nomos Xanthis: about $15 \mathrm{~km}$ NNW of Stauroupoli town, about $2 \frac{1}{2} \mathrm{~km} \mathrm{~N}$ of the village Livaditis, Rodopi Mts, at the Livaditis water fall. $41^{\circ} 19.639^{\prime} \mathrm{N} 24^{\circ} 40.316^{\prime}$ E. Fagus wood. N sloping ravine with water fall. Bedrock: quartzite. On boulder in the river bed. Alt. 896 m. 15.09.2017.

3) Nomos Xanthis: about $15 \mathrm{~km}$ NNW of Stauroupoli town, about $2 \frac{1}{2} \mathrm{~km} \mathrm{~N}$ of the village Livaditis, Rodopi Mts, along the path from Livaditis water fall to the gazebo at the forest track. $41^{\circ} 19.606^{\prime} \mathrm{N} 24^{\circ} 40.438$ 'E. Fagus wood on N slope, incl. 40. Bedrock: granite. Alt. 930-974 m. 15.09.2017.

4) Nomos Xanthis: about $14 \mathrm{~km}$ WNW of Xanthi town, $2 \frac{1}{2} 2 \mathrm{~km}$ E of Stauropolis. $41^{\circ} 12^{\prime} 20.5^{\prime \prime N} 24^{\circ} 43^{\prime 2} 28.6^{\prime \prime E}$. SW sloping mountain side. Road cutting in limestone rocks. On ledges. Alt. 275 m. 26.09.2015.

\section{List of species}

** designates new to the Greek mainland; * designates new to Thrace; Q.f. = Quercus frainetto

* Amandinea punctata (Hoffm.) Coppins \& Scheid. - On trunk of Q.f.; 1: (with Lecanora chlarotera 15838, Lecanora rugosella 15854).

* Buellia erubescens Arnold - On trunk of Q.f.; 1: 15850, (with Lecanora chlarotera 15858).

* Caloplaca ferruginea (Huds.) Th.Fr. - On trunk of Q.f.; 1: 15840.

** Cladonia caespiticia (Pers.) Flörke - On earth brink along path; 3: 15875.

* Cladonia fimbriata (L.) Fr. - On moss and litter on the ground; 3: 15871x.

Cladonia foliacea (Huds.) Willd. - On moss on shallow soil on limestone ledge; 4: 15371. - Not stated for Thrace by Аввотт (2009), recorded, however, by Szatala (1940).

* Cladonia glauca Flörke - On moss on the ground; 3: 15871.

* Cladonia pocillum (Ach.) Grognot - On moss on shallow soil on limestone ledge; 4: 15367.

* Cladonia pyxidata (L.) Hoffm. - On moss among exposed Fagus roots; 2: 15864.

* Collema crispum (Huds.) F.H.Wigg. (Blennothallia crispa (Huds.) Otálora et al.) - On shallow soil on limestone ledge; 4: 15370.

* Collema cristatum (L.) F.H.Wigg. (Lathagrium christatum (L.) Otálora et al.) - On moss on shallow soil on limestone ledge; 4: 15366.

* Collema flaccidum (Ach.) Ach. - On bark at the base of trunk of Q.f. and on quartzite rock wall; $\mathbf{1}$ : 15852. 2: 15861, 15870.

* Collema furfuraceum (Arnold.) Du Rietz - On trunk of Q.f.; 1: 15843.

* Collema subflaccidum Degel. - On trunk of Q.f.; 1: 15857. 
* Collema tenax (Sw.) Ach. (Enchylium tenax (Sw.) Gray) - On shallow soil on limestone ledge; 4: (with Collema crispum 15370).

** Dermatocarpon luridum (With.) J.R.Laundon - On quartzite rock in the stream; 2: 15868.

Flavoparmelia caperata (L.) Hale - On bark at the base of trunk of Q.f.; 1: 15841. - Two previous records from Thrace (Аввотт 2009).

* Lecanora chlarotera Nyl. - On trunk of Q.f.; 1: 15838, 15858.

* Lecanora intumescens (Rebent.) Rabenh. - On trunk of Q.f.; 1: 15851.

* Lecanora pruinosa Chaub. - On limestone ledge; 4: 15369.

* Lecanora pulicaris (Pers.) Ach. - On trunk of Q.f.; 1: (with Lecanora intumescens 15851.)

*Lecanora rugosella Zahlbr. - On trunk of Q.f.; 1: 15846, 15854.

* Lecidella euphorea (Flörke) Kremp. - On trunk of Q.f.; 1: (with Lecanora rugosella 15846).

* Leptogium cyanescens (Ach.) Körb. - On moss on granite outcrop; 3: 15872. - According to Аввотт (2009) not known from the Greek mainland, but subsequently recorded by CHRISTENSEN (2014) from Epirus.

Leptogium lichenoides (L.) Zahlbr. (Scytinium lichenoides (L.) Otálora et al.) - On moss on quartzite rock wall, on moss on quartzite boulder in stream and on moss on granite outcrop; 2: 15863, 15865, 15866. 3: 15873. - One previous record for Thrace (Аввотт 2009).

* Melanelixia glabratula (Lamy ex Nyl.) Sandler Berlin \& Arup - On trunk of Q.f.; 1: 15847.

* Melanohalea exasperatula (Nyl.) O.Blanco et al. - On trunk of Q.f.; 1: (with Buellia erubescens 15850).

* Ochrolechia szatalaensis Verseghy - On trunk of Q.f.; 1: 15845.

* Ochrolechia turneri (Sm.) Zopf - On trunk of Q.f.; 1: 15856.

Parmelia sulcata Taylor - On trunk of Q.f.; 1: 15844. - Reported from three localities in Thrace (Аввотт 2009).

* Parmelina quercina (Willd.) Hale - On trunk of Q.f.; 1: 15834, 15859.

Parmelina tiliacea (Hoffm.) Hale - On trunk of Q.f.; 1: 15835, 15848. - Reported from one locality in Thrace (Аввотт 2009).

* Peltigera praetextata (Flörke ex Sommerf.) Zopf - On moss on quartzite boulder in stream and on moss on granite boulder; 2: 15867. 3: 15874.

* Pertusaria albescens (Huds.) M.Choisy \& Werner var. albescens - On trunk of Q.f.; 1: 15833, 15849, 15855.

Pertusaria hymenea (Ach.) Schaer. - On trunk of Q.f.; 1: 15853. - One previous record for Thrace (Аввотт 2009).

* Pertusaria pertusa (Weigel) Tuck. var. pertusa - On trunk of Q.f.; 1: 15839.

* Physcia aipolia (Ehrh. ex Humb.) Fürnr. - On trunk of Q.f.; 1: 15842.

* Physcia dubia (Hoffm.) Lettau - On quartzite rock wall; 2: 15862 (teretiuscula type).

* Physconia enteroxantha (Nyl.) Poelt - On trunk of Q.f.; 1: 15860.

* Physconia servitii (Nàdv.) Poelt - On trunk of Q.f.; 1: (with Ochrolechia turneri 15856).

Pleurosticta acetabulum (Neck.) Elix \& Lumbsch - On trunk of Q.f.; 1: 15837. - Known from four localities in Thrace (Аввотт 2009). 
* Rinodina pyrina (Ach.) Arnold - On trunk of Q.f.; 1: (with Lecanora chlarotera 15838, Lecanora rugosella 15854).

* Sarcogyne regularis Körb. - On limestone ledge; 4: 15368.

** Vahliella leucophaea (Vahl) P.M.Jørg. - On granite outcrop in Fagus wood. 3: Shade form with discrete blue-grey squamules on a prominent black hypothallus (cf. JøRGENSEN 1978). Not collected due to its position on the middle of a smooth surface - photographically documented.

Xanthoria parietina (L.) Th.Fr. - On trunk of Q.f. 1: 15836. - Known from four localities in Thrace (Аввотт 2009).

\section{Discussion}

Cladonia caespiticia (one earlier report of uncertain position, probably Corfu, Аввотт 2009), Dermatocarpon luridum (reported once from Crete, Аввотт 2009), and Vahliella leucophaea (known from Crete, Аввотт 2009) are new to the Greek mainland. This paper reports 45 lichens for Thrace, increasing the number of known lichen species in Thrace from 32 to 69 and for nomos Xanthi from 14 to 51. The fact that 37 of the collected 45 lichen species are new to Thrace underlines the poor knowledge of this north-easternmost part of the Greek mainland. Dermatocarpon luridum hitherto known from Crete only occurs in all likelihood in more riverine environments throughout Greece as this seems to be a biotope that is currently under-collected.

MugGia et al. (2018) investigated sacred groves in Epirus. The dominant trees in the groves were different oak species, among them Quercus frainetto. It is, however, not possible to see from their species list which lichen species grew on $Q$. frainetto. Hence, the species list brought here is the first proper report on lichens on Quercus frainetto in Greece (loc. 1). The site was an open Quercus frainetto woodland with Acer monspessulanum and Carpinus on a small ridge with limestone outcrops. A shepherds summer camp was at the margin of the woodland and herds of sheep and goats were grazing the grassland below and between the trees. The lichen species found mainly belong to the Xanthorion alliance, an assembly of corticolous species on well lit and nutrient enriched bark in moderately humid environments (KLEMENT 1955, JAMES et al. 1977). The genus Quercus generally has acidic and nutrient poor bark, but judged from the species composition the dry, dusty limestone environment and the nutrient enrichment of the goat and sheep dung have made the bark more basic and nutrient rich.

Epigeic and epilithic lichens were collected from a north sloping dense Fagus sylvatica wood in a ravine (loc. 2 \& 3). Cladonia caespiticia, C. fimbriata, C. glauca, and C. pyxidata are all common and widespread species in Fagus woods in Europe. Collema flaccidum, Leptogium cyanescens, L. lichenoides, Peltigera praetextata, and Vahliella leucophaea, growing either directly on rock or among moss on rock, occur in humid forest environments.

Cladonia foliacea, C. pocillum, Collema crispum, C. cristatum, C. tenax, Lecanora pruinosa, and Sarcogyne regularis (loc. 4) all occur commonly on sun-exposed limestone rocks in Greece.

\section{Acknowledgements}

This paper is dedicated to Helmut MAYRHOFER in recognition of his substantial contribution to the lichenized mycota of the Balkans. 


\section{References}

Аввотт B.F.M. 2009: Checklist of the lichens and lichenicolous fungi of Greece. - Bibliotheca Lichenologica 103: $1-368$.

ARCADIA L. 2018: Atlas of Greek lichens. - URL: http://www.lichensofgreece.com/atlas.html [last accessed 22 January, 2018].

Christensen S.N. 2014: The epiphytic lichen flora of Platanus orientalis stands in Greece. - Willdenowia 44: $209-227$.

Christensen S.N. 2018: Lichens of Picea abies woodlands in Greece. - Herzogia 31: 219-230.

James P., Hawksworth D.L. \& Rose F. 1977: Lichen communities in the British Isles: A preliminary conspectus. In: Seaward M.R.D. (editor). Lichen ecology. 295-413. Academic Press (London, New York, San Francisco).

Jørgensen P. M. 1978: The lichen family Pannariaceae in Europe. - Opera Botanica 45: 1-124.

KLEmENT O. 1955: Prodromus der mitteleuropäischen Flechtengesellschaften. - Feddes Repertorium specierum novarum regni vegetabilis, Beiheft 135: 5-194.

Muggia L., Kati V., Rohrer A., Halley \& Mayrhofer H. 2018: Species diversity of lichens in the sacred groves of Epirus (Greece). - Herzogia 31: 231-244.

Smith C.W., Aptroot A., Coppins B.J., Fletcher A., Gilbert O.L., James P.W. \& Wolseley P.A. (editors) 2009: The lichens of Great Britain and Ireland. - British Lichen Society (London).

Szatala Ö. 1940: Adatok a Balkánfélsziget és Kis-Ázsia zuzmóflórájának ismeretéhez - Contributions a la connaissance de la flore lichénologique de la péninsule des Balkans et de l'Asie Mineure. - Borbásia Dissertationes Botanicae 2: 33-50.

Manuscript accepted: 12 February 2018

Communicated by: Philipp Resl

\section{Address of the author}

Steen N. CHRISTENSEN, Natural History Museum of Denmark, Botanical Garden \& Museum, University of Copenhagen, Sølvgade 83, Entr. S, 1307 Copenhagen K, Denmark. E-mail: steenc@snm.ku.dk 